\title{
The historic city and the East-West exchange: architecture, urban renewal and international knowledge transfers under state socialism in Hungary
}

\author{
Erika Szívós* (iD \\ Institute of History, Department of Economic and Social History, Eötvös Loránd University, H-1088 \\ Budapest, Múzeum krt. 6-8, Hungary \\ ${ }^{\star}$ Corresponding author. Email: szivos.erika@btk.elte.hu
}

\begin{abstract}
In recent years, the permeability of the Iron Curtain seems to have become a new paradigm in the field of post-war history - urban history included. It is clear, however, that significant differences existed among Eastern Bloc countries in terms of how open they were to Western influences, and to what extent their governments allowed those countries' citizens - professionals among them - to gain experiences abroad. This article investigates the ways city planning and heritage policy in state socialist Hungary were influenced by international trends; it explores the roles Hungarian architects, urban planners and other experts played after 1956 in knowledge transfers, i.e. the transmission of novel ideas in the field of architecture and urban planning, with special regard to the renewal of inner-city areas and historic town centres. Besides reflecting critically on concepts of the strict East-West divide, the article also calls attention to the limits of freedom inherent even in a relatively liberal Eastern Bloc regime: various forms of state control - including state security surveillance - continued to characterize the system until its collapse in 1989, affecting the mobility of urbanists and architects as well as all other professional groups.
\end{abstract}

Policies of urban heritage protection are rarely forged in politically neutral environments; rather, they tend to develop within particular power fields, and they bear the marks of the broader political contexts in which they were conceived. The fates of historic urban centres in state socialist Hungary (1948-89), just like in other Eastern Bloc countries, were always determined by political tides, and were influenced by both ideological and practical priorities of central planning. Political considerations, however, were neither uniform nor constant during the four long decades of state socialism; the official attitudes towards historic city centres changed continually in Hungary between 1945 and 1990.

In this article, I will focus on Hungary's capital city Budapest, examining the ways the protection of architectural heritage and ideas of inner-city renewal gained legitimacy during the Cold War era. I will reflect on the role of international re-use, distribution, and reproduction in any medium, provided the original work is properly cited. 
influences in the process, placing my own work within a distinct current of recent scholarship whose representatives have challenged earlier notions of the strict EastWest divide and called attention to the 'porosity' or 'semi-permeability' of the Iron Curtain during the post-Stalinist period and late socialism. ${ }^{1}$ Scholars who represent this approach point to the important role of transfers in the fields of culture, science and technology, emphasizing the intensity of exchange between Eastern Bloc countries and the developed West, but also between the Soviet Union, its Central and Eastern European satellite states (together referred to as the 'Second World') and countries of the 'Third World'. ${ }^{2}$ In this article, the exchange between East and West and the contacts between Hungary and the rest of the world will be understood on various levels. The first two sections will investigate the ways Hungarian architecture, urban planning and policies of urban renewal were influenced by international trends and knowledge transfers, involving, among other things, the international mobility of architects and other experts. The last section seeks to reveal a less explicit aspect of East-West connections: it will reflect on the limits of freedom inherent in the system, and investigate the ways architects, professional relations and international mobility were affected by state control, including state security surveillance.

Besides being a contribution to a growing field, this article is meant to be a tribute to my late professor, mentor and colleague Vera Bácskai, to whose memory the present special section is devoted. Vera Bácskai's whole oeuvre was related to historic cities, and although she was an urban historian and not an architect, she shared most of those experiences which the protagonists of this article - architects, urban planners and conservationists - lived through under state socialism. Her life and career epitomized the phenomena which are discussed in the sections below. Even though Vera Bácskai and her family were directly and brutally affected by the suppression of the 1956 revolution, the opening up of East-West relations and the limited liberalization of professional travel made it possible for her gradually to establish contacts with scholars and institutions in Western Europe, first and foremost in Britain; these professional and personal friendships are vividly described in this volume by Peter Clark, and have recently been memorialized in an online article by another contributor to this volume, Penelope Corfield. ${ }^{3}$

\footnotetext{
${ }^{1}$ See e.g. M. David-Fox, 'The Iron Curtain as semipermeable membrane: origins and demise of the Stalinist superiority complex', in P. Babiracki and K. Zimmer (eds.), Cold War Crossings: International Travel and Exchange across the Soviet Bloc, 1940s-1960s (Austin, 2014), 14-39.

${ }^{2}$ Works of urban and architectural historians who have critically reassessed earlier assumptions about the isolation of Soviet-dominated countries and emphasized international transfers have been particularly relevant for this article. See e.g. D. Bocharnikova and A. Kurg, 'Introduction: urban planning and architecture of late socialism', Journal of Architecture, 24 (2019), 593-603; C. Popescu, 'Introductory argument: architecture of the Communist bloc in the mirror', Journal of Architecture, 14 (2009), 1-6; Á. Moravánszky, T. Lange, J. Hopfengärtner and K. Kegler (eds.), East West Central: Re-Building Europe, 1950-1990 (Basel, 2017). In this article, I will keep the terms 'Second World' and 'Third World' but use them between quotation marks to indicate that those terms, coined in the Cold War era, embodied a particular historical period's usage and way of thinking. Since then, 'Third World' has been gradually abandoned and replaced by other preferences such as the 'Global South'.

${ }^{3}$ See P.J. Corfield, 'Honouring Vera Bácskai, 1930-2018', in www.penelopejcorfield.com/monthly-blogs/ 109 (Jan. 2020).
} 
The darkest side of the state socialist politics of control, also discussed in my present article, did not spare Vera Bácskai either. In a dramatic moment of her life in the mid-2000s, Vera Bácskai was forced to learn that she and members of her family had been under state security surveillance for several years, and that surveillance infiltrated into her most intimate family circles. I therefore dedicate this work to a scholar who always bore the burden of history in the most upright manner, and who, despite all obstacles, devoted a great part of her career to building bridges between her home country and the international scholarly community.

\section{Approaches towards the historic city: changing attitudes between the $1940 \mathrm{~s}$ and the 1980s}

\section{The period of official ambivalence, 1948-c. 1975}

In earlier works of historical urban studies, it has generally been assumed that historic towns, old city centres and their historic building stock were undervalued and largely neglected during the first few decades of state socialist regimes in East Central European countries (including Hungary), at least in the sense that their systematic renewal was not among the priorities of urban policy-making.

As far as Hungary is concerned, post-war governments indeed had several reasons to relegate urban renewal into the realm of remote and indefinitely postponed plans. Hungary and especially its capital city Budapest suffered serious damages during World War II, so the repair of war damage and the pressing tasks of reconstruction absorbed most of the available resources during the immediate post-war years.

Then, after the Communist takeover in 1948-49, the Stalinist model was adopted, and industrialization came to be regarded as a top priority in Hungary; the construction of 'socialist cities', related to heavy industry and mining, was given preference over other investments, ${ }^{4}$ while state-sponsored residential construction in other cities remained minimal. After 1953, when - correcting the policies of the previous years - new programmes were forged to alleviate the housing shortage in Budapest and in other larger cities, attention was focused on the erection of new housing estates, together with some grandiose - in many cases unrealized - plans for the creation of new town centres in the new 'socialist' spirit. ${ }^{5}$ In general, the preference given to the construction of new housing over the revitalization of old residential neighbourhoods characterized the whole long period between 1953 and 1975, and the problem of decaying inner-city areas was repeatedly put aside as a task to be addressed in the indefinite future.

\footnotetext{
${ }^{4}$ The first and representative new city of the Stalinist period in Hungary was Sztálinváros (Stalin City, today Dunaújváros). See S. Horváth, Stalinism Reloaded: Everyday Life in Stalin-City, Hungary (Bloomington, 2017). For socialist cities in Hungary and East Central Europe, see also P. Germuska, Indusztria büvöletében. Fejlesztéspolitika és a szocialista városok (Budapest, 2004).

${ }^{5}$ It is a less-well-known side of the Stalinist and post-Stalinist periods in Hungary that from the 1950s the state-sponsored construction of urban housing estates was complemented by the widespread, privately financed construction of detached houses in the countryside, and also by other forms of private investment such as residential construction financed by housing co-operatives. See M. Keller, Indokolt lakásszükséglet: A lakáspolitika az 1950-es években (Budapest, 2012), 42-9; V. Molnár, Building the State: Architecture, Politics, and State Formation in Post-War Central Europe (London, 2013), 71-5.
} 
Besides neglect, the widespread disrespect for historic architecture also represented dangers for old town cores and historic districts throughout the same period. Several instances could be cited from Hungary, as with other countries in Central and Eastern Europe, to illustrate the inconsiderate treatment of old city cores and the lack of respect for their historic urban fabric in the state socialist period, which was manifest in demolitions and radical inner-city reconstruction projects - always hailed as the triumph of socialist modernity over the outdated architecture and obsolete town planning principles of earlier, 'capitalist' periods. Except for the brief period of 1949-53, when, under Soviet influence, the monumental and conservative style of socialist realism became compulsory in architecture, the modernist idiom as well as the technocratic approach to urban planning was heartily endorsed by most Hungarian architects and, after the mid-1950s, also by the political elite. As is well known, neither the philosophy of architectural modernism nor the technocratic practice prevalent during the post-war decades held historic neighbourhoods in very high esteem. Already before the Communist takeover, most members of the planning profession agreed that outside the innermost core of Budapest - the district called the Inner City - the average historic residential neighbourhoods and their building stock were 'worthless' and ripe for demolition. ${ }^{6}$ At an urban planning symposium in November 1953, several participants raised the issue of how to modernize Budapest's old inner-city areas (primarily Districts VI-IX), which they thought was only possible by large-scale demolitions, if not within 10 years then in the subsequent period. ${ }^{7}$ For fairness' sake, the negative attitude towards old residential districts and their historic architecture, as is amply documented by comparative architectural histories, was not at all unique to Communist states, but was as characteristic of Western planning practices as of East Central and Eastern European ones during the period of high modernism - or, to use a different terminology, during the Fordist phase of urban planning. ${ }^{8}$

In any case, the continuity between inter-war and post-war modernism, manifest in several architects' careers, was quite apparent in Hungary, just as it was in other countries of East Central Europe. ${ }^{9}$ Several members of the architectural profession, e.g. József Fischer (1901-95), Gábor Preisich (1909-98), Mihály Vadász (1900-67) or Máté Major (1904-86), had started their careers in the inter-war period, becoming major representatives of modernism in the 1930s; after World War II, they resumed their work in the same spirit, some of them assuming responsible positions in various urban planning organizations and offices, provided they were

\footnotetext{
${ }^{6}$ See G. Preisich, Budapest városépitésének története 1945-1990 (Budapest, 1998), 74. Preisich here summarized the principles of the General Development Plan of Budapest, prepared by the Budapest Council of Public Works between 1945 and 1947.

${ }^{7}$ G. Preisich, A. Sós and J. Brenner (eds.), Budapest városépitészeti kérdései. Az 1953. november 20-21-én tartott ankét anyaga (Budapest, 1954), 15, 25, 39, 57.

${ }^{8}$ See e.g. V.M. Lampugnani, Die Stadt im 20. Jahrhundert. Visionen, Entwürfe, Gebautes (Berlin, 2011), vol. II, 753-88.

${ }^{9}$ Recent summaries of East Central European modernism all emphasize the continuities between the inter-war and post-war periods in terms of paradigms as well as architects' careers. See e.g. M. Kohlrausch, Brokers of Modernity: East Central Europe and the Rise of Modernist Architects, 1910-1950 (Leuven, 2019); see also K.E. Zarecor, Manufacturing a Socialist Modernity: Housing in Czechoslovakia 1945-1960 (Pittsburgh, 2011), 13-68.
} 
considered politically reliable. When the Stalinist period ended and modernist architecture was rehabilitated in Hungary, these architects - if they did not emigrate in 1956 - returned to modernism and functionalism as both practising planners and policy-makers. This third period of modernism, beginning in the second half of the 1950s, produced several successful and aesthetic examples of modern housing, such as the experimental housing estate of Obuda (District III), the housing estate of Lágymányos (District XI $)^{10}$ and even some remarkable public buildings in Hungary; but it was also earmarked by the increasing dominance of technocratic thinking which concentrated on the industrialized mass production of housing, culminating in the construction of large prefabricated housing estates after the mid-1960s. ${ }^{11}$

The reigning urban planning philosophies of that period were anything but merciful towards old residential neighbourhoods, many of which, especially in outer districts but sometimes in inner-city areas too, were cleared away to make room for extensive prefabricated housing estates. ${ }^{12}$ But it would be a gross simplification to identify that dominant trend as the only one. It is more correct to say that conservationist efforts were always present in state socialist Hungary, even if they were, in some periods, strongly overshadowed by modernizing impulses.

It would be a mistake to assume that historic towns and city centres were viewed in exclusively negative terms by Communist governments and urban planning experts. The appreciation of historic heritage and the effort to preserve architectural monuments never disappeared in Hungary, either during the Stalinist period, or during the 1960s when functionalist trends and Fordist approaches to urban planning reached their zenith in European architecture on both sides of the Iron Curtain.

Although a fully independent national organization of heritage conservation was not set up in Hungary until 1957, its national co-ordinative organ named the National Committee of Monuments (Mủemlékek Országos Bizottsága) - established in 1881 - did continue to exist in the post-war period, replaced in 1949 by the National Centre of Museums and Monuments (Múzeumok és Müemlékek Országos Központja), an organ subordinated to other, larger governmental institutions. ${ }^{13}$ The field of monument conservation was re-regulated in 1949, the new

\footnotetext{
${ }^{10}$ On successful examples of modernist housing experiments, see e.g. M. Branczik and M. Keller, Korszerü lakás - 1960: Az óbudai kísérlet (Budapest, 2011); M. Keller, 'Modernität im Osten: die Óbudaer Versuchswohnsiedlung in Ungarn. Theoretische Ansätze und ihre Probleme', in O. Fejtová, V. Ledvinka and J. Pešek (eds.), Europäische Großstädte zwischen dem Ende des Zweiten Weltkrieges und dem Ende des Kalten Krieges (1945-1989) (Prague, 2011), 277-91; see also Preisich, Budapest városépitésének története 1945-1990, 79-81.

${ }^{11}$ On the concepts and practice of the mass production of housing in Hungary, see Molnár, Building the State; specifically for Budapest, see Preisich, Budapest városépitésének története 1945-1990, 78-93; A. Ferkai, Housing Estates (Budapest, 2005); and A. Csizmady, A lakótelep (Budapest, 2003), 84-97.

${ }^{12}$ On the spatial patterns of prefabricated housing projects between the late 1960 s and the late $1980 \mathrm{~s}-$ as well as those of earlier housing estates - in Budapest, see Csizmady, A lakótelep, 89.

${ }^{13}$ For a detailed coverage of the organizational framework, see M. Magyar and A. Péter (eds.), $A z$ épitészeti örökség védelme (Budapest, 2003), 13-24; L. Prosinger, 'A Batthyány téri barokk műemlékegyüttes műemlékegyüttes tervezett lebontása és sikeres megmenekülése’, URBS Magyar Várostörténeti Évkönyv, 6 (2011), 236-8; I. Fekete, 'Műemlékvédelem és örökség Magyarországon. Intézménytörténet, perspektívák, vélemények', Világosság, 45 (2005), 102-8.
} 
regulations replacing the 1881 Monuments Act still in effect at that time. Also, the first full national cadastre of architectural monuments was compiled by István Genthon in 1953, establishing the canon of built heritage in Hungary. Finally, the long-lived organ of heritage protection, the National Supervisory Office of Monuments (Országos Müemléki Felügyelőség) was established in 1957 under the Monuments Department of the Ministry of Construction Affairs (Építésügyi Minisztérium). ${ }^{14}$

Furthermore, the 1950s in Hungary were characterized by the increasing professionalization of heritage conservation and the relative strength of the conservationist profession despite the institutional and organizational uncertainties. This profession in the post-war decades mostly consisted of historians of art and architecture, such as István Genthon (1903-69), Dezső Dercsényi (1910-87), László Gerő (1909-95) and Géza Entz (1913-93), who began their careers in the inter-war period, already becoming renowned experts before World War II. Their expertise made them indispensable in the early Communist period as well and endowed them with substantial authority. In some cases, the lobbying power of the profession was strong enough to prevent the demolition of significant ecclesiastical buildings. A notable example was St Anne's Church and the adjoining monastery at Batthyány Square, Budapest; monument conservation experts successfully lobbied for and rescued that building complex in the early 1950s, despite the destructive intentions of no less a person than Hungary's dictator Mátyás Rákosi. ${ }^{15}$ Sometimes in latent and sometimes in manifest ways, monument conservation experts always had some chance to assert their professional convictions, occasionally, as shown above, rescuing endangered monuments even in the darkest days of Stalinist dictatorship.

In fact, 'socialist realist' architecture, loyally adopted in Hungary between 1949 and 1953 and declared to be the only acceptable style until Stalin's death in March 1953, idealized the monumental and the classical, and was therefore not at all hostile to historic styles; rather, it wished to create structures and spaces that would equal - or surpass - works of the great masters of classical, neo-classical and historicist architecture. Besides, Stalinism in the Soviet Union as well as in its post-war satellite states in East Central Europe strove to reinvent national heritage and exploit it for its own purposes; for that reason, the preservation of architectural monuments was considered important from the point of view of national heritage policies. ${ }^{16}$

Preservationist policies in fact had been present throughout the history of the Soviet Union, and that fact provided an important point of orientation for Soviet satellite states after 1945. Of course, numerous instances of iconoclastic and

\footnotetext{
${ }^{14}$ Magyar and Péter (eds.), Az épitészeti örökség védelme, 21-4.

${ }^{15}$ For the details of the case and the rhetoric of the conservationists, see Prosinger, 'A Batthyány téri barokk mủemlékegyüttes', 235-59.

${ }^{16}$ On the relationship of late Stalinism to architectural heritage and conservation, and the compatibility of socialist realism with historic architecture, see A. Aman, Architecture and Ideology in Eastern Europe during the Stalin Era: An Aspect of Cold War History (New York, c. 1992). The positive attitude of Soviet cultural policy toward the built heritage is also highlighted by an excellent review by W. Lesnikowski, 'Architecture and ideology in Eastern Europe during the Stalin era: an aspect of Cold War history', Journal of Architectural Education, 48 (1995), 202.
} 
destructive actions against church buildings or palaces could be cited, especially from the early years of the Soviet state. However, as recent studies have shown, already in the early decades - between the early 1920s and 1940 - a complex, statefunded system of monument conservation emerged in the USSR, and although official attitudes towards historic architecture were at times controversial, several historic structures, ecclesiastical buildings included, were placed under protection as listed monuments. ${ }^{17}$ As Steven Maddox points out, the preservation of monuments - including a substantial part of the Tsarist era's architectural heritage began to receive strong official support in Stalin's Soviet Union in the 1930s; for patriotic reasons, the salvaging of landmark buildings and objects was considered an important goal even amidst the conditions of total war, i.e. between 1941 and $1944 .^{18}$ The underlying motivations were of course complex: whereas dedicated preservationists were concerned about major heritage buildings' artistic value and symbolic significance, and often the populace too felt a strong attachment to them, the authorities regarded pre-1917 landmark buildings as objects 'which reflected Russia's history of imperial expansion and glory. ${ }^{19}$ This adds yet another dimension to the problem: the Soviet Union, a great power with imperial ambitions, identified with the country's imperial legacy through the architecture of past centuries.

The question how non-Russian nations' heritage fitted into that vision is more daunting, however. Covering the selective treatment of outstanding monuments that were central to the identities of non-Russian nations and nationalities in various republics of the USSR is beyond the scope of this article, but it is an important problem to be addressed elsewhere. ${ }^{20}$

The cultivation of national architectural heritage in post-1945 Eastern Bloc countries, as was the case with the Soviet Union earlier, often involved the reconstruction of buildings - such as churches and palaces - whose original functions were difficult to reconcile with the dominant ideology of state socialism in the late 1940 s and 1950 s. $^{21}$ One way out of the dilemma was to keep those buildings and restore their architectural splendour but give them new, secular, social and cultural functions; deprived of their original meanings and 'reactionary' connotations,

\footnotetext{
${ }^{17}$ On the complexities of heritage conservation in the early USSR, see C. Kelly, 'Socialist churches: heritage preservation and "cultic buildings" in Leningrad, 1924-1940', Slavic Review, 71 (2012), 792-823; on certain period's controversial attitudes, see C. Kelly, 'The shock of the old: architectural preservation in Soviet Russia', Nations and Nationalism, 24 (2018), 88-119.

${ }^{18}$ S. Maddox, 'These monuments must be protected! The Stalinist turn to the past and historic preservation during the blockade of Leningrad', Russian Review, 70 (2011), 608-26, esp. 609; on the perseverance of preservationist intentions from the early days of Soviet Russia to the 1960s and beyond, see also V. Donovan, 'The "old new Russian town": modernization and architectural preservation in Russia's historic North West, 1961-1982', Slavonica, 19 (2013), 23-4.

${ }^{19}$ Maddox, 'These monuments must be protected!', 609.

${ }^{20}$ For an overview of ethnic politics in the USSR, with reflections on the significance of religious buildings and other monuments and their treatment, see L. Hajda, 'Ethnic politics and ethnic conflict in the USSR and the post-Soviet states', Humboldt Journal of Social Relations, 19 (1993), 193-278, esp. 203 and 226. On the controversies of officially declared Soviet policy versus the practice of monument conservation on the local level, see J.-L. Cohen, 'Soviet legal documents on the preservation of monuments', Future Anterior, 5 (2008), 62-3.

${ }^{21}$ Lesnikowski, 'Architecture and ideology', 202.
} 
the buildings could then be easily integrated into the canon of national architecture and could be viewed purely as monuments.

Although the Stalinist regime in Hungary - burdened by the demands of postwar reconstruction, an acute housing shortage and the country's duties to pay war reparations - could not mobilize significant resources for monument conservation, it did at least support the idea in principle, not least because Stalin's Soviet Union too laid emphasis on the protection and preservation of monuments. This was a solid argument which helped Hungary's Communist political elite explain why palaces of the former aristocracy and churches belonging to various denominations deserved protection.

Furthermore, the adverse attitude of the Hungarian Communist regime towards the architectural heritage of the past was clearly selective. Leading architects and urban planners of the period, for example, recognized certain outstanding historic buildings and urban zones of Budapest - such as the Opera House, the Parliament, the building of the Hungarian Academy of Sciences and Saint Stephen's Basilica, or the Inner City, the Danube embankments and the Castle District - as 'valuable', whereas they labelled others - e.g. a large part of Districts VI-IX with their late nineteenth-century residential building stock built in the style of historicism - as 'worthless', as is apparent from the documents of a 1953 urban planning symposium. ${ }^{22}$ Some of those value judgements went back to earlier classifications of historic buildings by art historians and preservation experts of the inter-war period. ${ }^{23}$

From the early 1960s, interest in historic cities began to increase gradually in all European countries. International conventions such as the 2nd International Congress of Architects and Technicians of Historic Monuments, which produced the Venice Charter of 1964 (officially the International Charter for the Conservation and Restoration of Monuments and Sites), ${ }^{24}$ were themselves signs of the growing international concern with the protection of historic towns and city centres. The technocratic spirit which pervaded urban planning during the post-war period made experts aware of the threats to which the architectural heritage of historic cities was exposed.

Those international developments clearly had an impact on Eastern Bloc countries, thanks to the delegates sent by those countries to international symposiums. Monument conservation experts from East Central Europe, for example, participated in the 1964 congress in Venice; two of them, namely the delegates of Yugoslavia and Czechoslovakia, took part in the drafting of the Charter as well. Hungary, just like other Central Eastern European countries, adopted the principles of the Venice Charter in its later practice.

The official ideology of 'proletarian internationalism' apart, national heritage even if that exact label was not yet used - was clearly important for state socialist Hungary. Nearly all East Central European Communist countries could be characterized by a nationalist bent; as mentioned before, similarly to other dictatorships, the Rákosi regime in Hungary selectively appropriated and exploited Hungarian

\footnotetext{
${ }^{22}$ Preisich, Sós and Brenner (eds.), Budapest városépitészeti kérdései, 11, 57, 60.

${ }^{23}$ A. Sipos, A jövő Budapestje: Városfejlesztési programok és rendezési tervek (Budapest, 2011), 56-63.

${ }^{24}$ The Venice Charter was adopted by ICOMOS in 1965. See www.icomos.org/charters/venice_e.pdf, last accessed 4 Feb. 2020.
} 
history and cultural heritage for its own purposes. So did the cultural policy of János Kádár's regime after 1956. Hungary's historic architecture - at least the most distinguished parts of it, the 'heritage value' of which was consensual occupied an important place in the greater project of educating the public about the nation's shared values.

As a sign of the renewed appreciation of architectural heritage, some major reconstruction projects were launched in Hungary in the early 1960s. For example, the residential section of the Buda Castle - the so-called burghers' town - underwent a thoroughgoing, complex renewal, which required the co-operation of several archaeologists, art historians and architects. During that renewal project, medieval and Renaissance foundations of Baroque town houses were discovered, and an explicit goal of the renovation work was to expose those early layers to the visiting public, making Renaissance frescoes and ornaments visible wherever possible. ${ }^{25}$ During the reconstruction of the Castle and the burghers' town, Hungarian archaeology was doing a pioneering job at a time when elsewhere in Europe the medieval period was still outside the purview of archaeological research. ${ }^{26}$

The project was part of the overall reconstruction of the Buda Castle, which suffered substantial damages during the siege of Budapest in 1944-45. After the earlier plans of the Stalinist period, aimed at the reconstruction of the Castle as a governmental power centre, had been dropped, the post-1956 plans reconceptualized the Castle's profile, endowing the former Royal Castle complex with new, cultural functions: the Hungarian National Gallery (Magyar Nemzeti Galéria), the National Széchenyi Library (Országos Széchenyi Könyvtár) and the Budapest History Museum (Budapest Történeti Múzeum) were to be moved into its various wings. ${ }^{27}$

\section{The turning of the tide: new ideas of urban renewal in Hungary, c. 1975-1990}

Although, as we have seen, Communist governments were in general committed to monument conservation, heritage protection approaches were rarely or never applied to extensive urban areas or entire inner-city zones until the late 1970s. Whereas, as we have seen, the protection of listed monuments, that is, architecturally outstanding or unique buildings, enjoyed relative consensus, the approach to 'average' historic districts and their 'one-in-a-dozen' buildings was much more controversial; inner-city tenement neighbourhoods of nineteenth-century origin or low-standard residential areas dominated by old, small-townish, one- or two-storey inner-courtyard buildings would often become the targets of radical reconstruction plans. Entire urban quarters like the old Óbuda (part of District III) were razed to the ground between 1968 and 1976, with only a main square and some streets spared and renovated in an open-air-museum-like manner. ${ }^{28}$

By the mid- to late 1970s, however, the problem of the built heritage began to receive increasing attention in Hungary. The 1970s witnessed the emergence of

\footnotetext{
${ }^{25} \mathrm{~K}$. Pereházy, A budavári lakónegyed rekonstrukciója (Budapest, 1982; 1986).

${ }^{26}$ On archaeological projects carried out in the Buda Castle District, see Z. Bencze, 'The Budapest History Museum and the rediscovery of medieval Buda', in B. Nagy, M. Rady, K. Szende and A. Vadas (eds.), Medieval Buda in Context (Leiden and Boston, MA, 2016), 25-51.

${ }^{27}$ About the completed project, see B. Kollányi, Az újjáépült Budavári Palota (Budapest, 1990).

${ }^{28}$ Preisich, Budapest városépitésének története 1945-1990, 84-5.
} 
more sympathetic attitudes towards historic inner cities all around Europe, and the practice of 'mild' renewal was increasingly preferred over radical reconstruction. Those trends began to influence Hungary too, affecting architects' professional discourse as well as policy-makers' decisions. ${ }^{29}$

The urban renewal experiments in Western and Northern European cities were followed closely by Budapest architects and authorities. ${ }^{30}$ Professional exchange within the Eastern Bloc was, for obvious reasons, even more intensive. The question of what to do with historic districts was increasingly often discussed in Hungarian professional circles after $1970 .{ }^{31}$

By the mid-1970s, the idea that elements of the built heritage which are not classified as monuments may also deserve protection gained legitimacy, and local councils increasingly often put old buildings under 'council protection' (i.e. protection on the local level). Newly constructed structures - if they were built in historic environments - were by then expected to harmonize with the surrounding historic urban fabric, and the regulations of new projects by the late 1970s and early 1980s reflected a growing respect for local architectural traditions. ${ }^{32}$

Ideas of urban renewal thus gradually gained ground among decision-makers in party and government circles in Hungary, and, finally, penetrated public discourse as well. Budapest planners, politicians and residents were particularly receptive to the new trends because, similarly to their Western European counterparts, the inner-city districts of Budapest were reaching critical stages of their lifecycles by the 1970s, and the decay was assuming increasingly threatening dimensions. The physical condition of the nineteenth-century building stock was rapidly deteriorating due to several decades of neglect, and the social and demographic consequences were no longer possible to ignore: the better-educated, mobile middle strata as well as the younger generations were noticeably deserting the inner districts, and the remaining population, rapidly decreasing in size, consisted increasingly of manual workers and senior residents. The inner districts of Budapest lost one third of their population between 1970 and 1980, while the population of Budapest as a whole grew by 3.7 per cent during the same period. ${ }^{33}$

The symptoms of physical and demographic crisis were described by statistical sources and sociological surveys, commissioned by the city council and carried out by the researchers working at the Urban Planning Company of Budapest (BUVÁTI - Budapesti Városépítési Tervező Vállalat). ${ }^{34}$ BUVÁTI had its own

\footnotetext{
${ }^{29}$ Cs. Jelinek, 'A városrehabilitáció korszakai Magyarországon: Az állam szerepe marginális városi terek (újra)termelésében', Tér és Társadalom, 33 (2019), 20-3.

${ }^{30} \mathrm{Cs}$. Jelinek, 'Uneven development, urban policy making and brokerage: urban rehabilitation policies in Hungary since the 1970s', Central European University Ph.D. thesis, 2017, 83.

${ }^{31}$ Ibid.

${ }^{32}$ A. Román, Müemlék, épitészeti örökség, város. Válogatás (cikkek és elöadások), 1970-1995 (Budapest, 1996), 34.

${ }^{33}$ É. Lampel and M. Lampel, Pesti bérházsors: várospolitika, városrehabilitáció (Budapest, 1998), 35-6; K. Tomay, 'Ferencváros és Józsefváros - két rehabilitációs kísérlet a fővárosban', in URBS Magyar Várostörténeti Évkönyv, 2 (2007), 328-9; E. Szívós, 'Terhes örökség. Budapest történelmi lakónegyedeinek problémája a Klauzál tér példáján', URBS Magyar Várostörténeti Évkönyv, 5 (2010) 386.

${ }^{34}$ See e.g. I. Szücs and M. Balázsné Varga, A Belsö-Erzsébetváros településszociológiai vizsgálata (Budapest, 1975). BUVÁTI was the acronym for Budapest Urban Planning Institute (Budapesti Várostervezési Intézet). The predecessor of this planning company of the capital city was created in
} 
research department, employing sociologists and other experts who were responsible for background research to support urban planning projects in the making. For example, they mapped out the social profile and residential composition of areas designated for renewal; but they also monitored the societal impact of completed projects. Those findings were often quoted in party documents, e.g. in minutes of local party and council meetings, in the late 1970s and 1980s. ${ }^{35}$

Thus, besides the general impact of heritage-sensitive urban planning trends emerging all around Europe, the tangible crisis symptoms on the local level too prompted architects and urban planners to reconsider their earlier attitudes towards the built heritage. For the same reason, party and council functionaries were also seeking solutions to the problem and were becoming open to the novel ideas of inner-city revitalization.

Urban renewal was soon receiving explicit political support. BUVÁTI, the planning company under the Budapest City Council, played a key role in the development of the principles and practical steps of urban renewal. For example, the company's experts made a proposal to renovate certain experimental blocks in Belső-Erzsébetváros (Inner Elizabethtown, part of District VII) and Terézváros (Theresatown, District VI); they elaborated the steps of the planned project and devised its budget. After their proposals were accepted by the city council in 1978, a decree was issued by the capital city, stating that the first experimental block renewal project should take place in District VII, beginning with Block $15 .^{36}$

The official turn was expressed by a party decree of 1978, stating that the protection of historic quarters and the renewal of old housing were just as important as the construction of new homes. ${ }^{37}$ This official statement in fact reflected rather than prompted the emergence of the new approach. Soon a comprehensive renewal scheme was developed for the Inner City, covering most of the multi-storey zones constructed in the nineteenth and early twentieth centuries. The Urban Renewal Concept of the Inner-City Districts of Budapest (Budapest belső kerületei

1948 under the name FŐTI (Planning Institute of the Capital City / Fővárosi Tervező Intézet); FŐTI was reorganized and renamed as BUVÁTI in 1950.

${ }^{35}$ See e.g. MSZMP VII. ker. Pártbizottság 1981. jún. 10-i ülése. Beszámoló az V. ötéves tervről és elöterjesztés a VI. ötéves tervről (Session of the District VII Committee of the Hungarian Socialist Workers' Party, 10 Jun. 1981. Report about the Fifth Five-Year Plan and proposal about the Sixth Five-Year Plan), Budapest City Archives (Budapest Föváros Levéltára, henceforth BFL) XXXV. 12. a. 3. 163. öe. 23-4); MSZMP VII. ker. Pártbizottság 1981. nov. 10-i ülése. 2. sz. melléklet. (Session of the District VII Committee of the Hungarian Socialist Workers' Party, 10 November 1981. Supplement 2) BFL XXXV.12. a. 3. 165. öe. These party documents are quoted in detail in Szívós, 'Terhes örökség', 390.

${ }^{36}$ Lampel and Lampel, Pesti bérházsors, 36. In-depth histories of the Block 15 regeneration project are provided, among others, by J. Hegedüs and I. Tosics, 'Gentrification in Eastern Europe: the case of Budapest', in J. Weesep and S. Musterd (eds.), Urban Housing for the Better-Off: Gentrification in Europe (Utrecht, 1991), 124-36.

${ }^{37} \mathrm{Az}$ MSZMP KB 1978 október 12-i kibővített ülése. A lakásépítés és lakásgazdálkodás 1990-ig szóló tervének irányelvei. Havasi Ferenc hozzászólása (Expanded session of the Central Committee of the Hungarian Socialist Workers' Party, 12 October 1978. The principles of the plan on housing construction and housing policy to 1990. The contribution of Ferenc Havasi), Hungarian National Archives (Magyar Nemzeti Levéltár Országos Levéltára), M-KS 288. fond 4/158 őe. 
rehabilitációjának koncepciója) was officially proposed by the Budapest City Council and was approved by the government in 1986, updated four years later. ${ }^{38}$

The 1986 concept set goals that were entirely consistent with the principles of 'mild' or 'soft' urban regeneration, by then widely adopted all around Europe. A particularly important statement of the 1986 document declared that 'the historically developed structure of the districts must be preserved, together with their architectural values and characteristic image'. ${ }^{39}$ As far as the timing and financing was concerned, the urban renewal concept also contained a long-term schedule. Between 1986 and 2000, 394 residential blocks were to be renewed, but out of these only 13 were to be completed until 1990, which reflected the pragmatic sense of the programme's planners; the majority of block renewal projects was scheduled for the late 1990s and 2000s. ${ }^{40}$

However, the greatest weakness of the comprehensive urban renewal programme of Budapest was the fact that it was conceived under the conditions of planned economy and was designed to be financed predominantly by state funds. The ambitious plans therefore remained largely unrealized; the overarching renewal of the Pest side's historic residential belt, to be financed from the central state budget, never took place. At the end of the Kádár era, amidst the economic difficulties and severe indebtedness of late socialist Hungary, ${ }^{41}$ there were no longer sufficient funds and realistic chances to carry out such grand projects. The general urban regeneration of the districts where promising block-level experimental projects ${ }^{42}$ took place in the mid-1980s in most cases did not reach a further stage. In 1990, the historic inner districts of Budapest entered the post-Communist period more or less in the same condition in which World War II had found it them in the early 1940s.

\section{Knowledge transfers}

But how exactly and by whom did ideas of urban renewal and urban heritage protection get transferred across the Iron Curtain? In general, how did international architectural influences or currents reach Hungary at times when - in countries of the Eastern Bloc - information exchange was strictly controlled, travel opportunities were limited and Western journals or books were not - one would assume - easily

\footnotetext{
${ }^{38}$ Budapest belsö kerületei rehabilitációjának koncepciója (Urban Renewal Concept of the Inner-City Districts of Budapest), Budapest Fővárosi Tanács VB, 1986; Budapest belső területeinek rehabilitációja, Budapest Főváros Tanácsa VB, 1990. Summarized also in Z. Cséfalvay, 'Várospusztulás és városfelújitás, 1945-1989', in E. Lichtenberger, Z. Cséfalvay and M. Paal, Várospusztulás - városfelújitás Budapesten (Budapest, 1995), 34-5.

${ }^{39}$ Lampel and Lampel, Pesti bérházsors, 39; Cséfalvay, 'Várospusztulás és városfelújítás, 1945-1989', 33.

${ }^{40}$ Lampel and Lampel, Pesti bérházsors, 39.

${ }^{41}$ Not only works on the history of urban renewal but also general histories of Hungary emphasize the fact that, following the oil crisis of 1973 , late socialist Hungary gradually became a gravely indebted country which was increasingly forced to prop up its inefficient economy and maintain its state-funded social security, health and educational systems by international loans. See e.g. I. Romsics, Magyarország története a XX. Században, 4th rev. edn (Budapest, 2010), 311; G. Földes, Az eladósodás politikatörténete, 1957-1986 (Budapest, 1995).

${ }^{42}$ The individual block-level revitalization projects are described in detail and documented by photos in Lampel and Lampel, Pesti bérházsors, 88-131.
} 
available? And is it at all justifiable to interpret Hungary's international relations exclusively in the East-West dichotomy, or were its international relations including economic and professional relations - more multilateral?

First of all, when it comes to professional relations, the divisive impact of the Iron Curtain seems exaggerated in retrospect; at least, one has to distinguish between sub-periods. The question of Hungarian foreign relations and professional exchange can be conveniently interpreted in the recent new paradigm of East-West relations, the proponents of which, as mentioned at the beginning of this article, deny the complete isolation of East from West during the Cold War period, and emphasize the multi-dimensional exchange taking place among countries of the Eastern Bloc and the rest of the world. In addition, some Hungarian historians stress the early impact of de-Stalinization on the Soviet Union and on Hungary, noticeable already in 1953. Examining the field of cultural relations, for example, Róbert Takács traces the history of renewed transfers and cultural exchange back to 1953 , to the beginnings of the Khrushchev era, ${ }^{43}$ while Melinda Kalmár stresses the great powers' mutual interests and motivations in re-establishing political, economic and cultural connections during the period of 'the thaw'. ${ }^{44}$

In any case, by the second half of the 1950s, and especially after 1960, Hungary was no longer hermetically closed off. Hungarian architects, urban planners and monument conservation experts had several opportunities to exchange ideas with their foreign colleagues, Western experts included, during international symposiums, study trips and the regular visits of delegations to and from Hungary. ${ }^{45}$ Architects' memoirs and biographies amply inform us about such possibilities, as do published and unpublished interviews.

Pál Granasztói (1908-85), a member of the generation whose career began in the inter-war period, was a particularly prolific writer and autobiographer, besides being an urbanist employed by municipal offices and ministries throughout most of his life. In one of his autobiographical essays, ${ }^{46}$ he provided a clear picture of Hungarian architects' international mobility, indicating in which historical periods they had the freedom to travel and in which periods they did not. The dividing dates are fairly clear: 1948-49, the time of the Communist takeover in Hungary, and 1956, the year of the Hungarian revolution. Before 1949, Granasztói could easily visit émigré colleagues - architects who had emigrated from Hungary before or shortly after World War II - in Switzerland or France, and could participate in an international symposium of CIAM (Congrès Internationaux d'Architecture Moderne) in London with some of his Hungarian colleagues. ${ }^{47}$ But his trip to London in 1948 was the last occasion for a long time. During the following eight years, Granasztói could not set foot in Western Europe again, and neither could

\footnotetext{
${ }^{43}$ R. Takács, 'Szovjet és magyar nyitás a kultúrában Nyugat felé 1953-1964', Múltunk, 27 (2015), 30-68; and R. Takács, 'Hungarian foreign policy and Basket III in the Cold War confrontation from Helsinki to Madrid', Múltunk, 31 (2019), Special Issue, 64.

${ }^{44} \mathrm{M}$. Kalmár, Történelmi galaxisok vonzásában: Magyarország és a szovjetrendszer 1945-1990 (Budapest, 2014), 81-6. See also M. Kalmár, 'The decades of détente', Múltunk, 31 (2019), Special Issue, 28-31.

${ }^{45}$ For the broad networks of conservationists and their international co-operations in the 1970s and 1980s, see M. Harlov, 'Műemlékvédelem: kapocs a világgal', Múltunk, 28 (2016), 125-30.

${ }^{46} \mathrm{P}$. Granasztói, Itthon éltem (Budapest, 1984).

${ }^{47}$ Ibid., 596-618.
} 
most of his colleagues. For Hungarians, travel barriers were almost complete between 1949 and 1956, except for the massive emigration wave occasioned by the revolution in October 1956.

An exceptional - albeit strongly controlled - opportunity was the 1958 World Exhibition in Brussels, but only for a limited number of professionals, namely those architects, led by Lajos Gádoros, who were responsible for the design of the Hungarian pavilion at the Brussels expo. (The same was true of Communist Czechoslovakia, but for Czech architects the expo brought about a major triumph: the Czechoslovak pavilion won a prize in Brussels in 1958.) For the Hungarians, the world fair was a challenging occasion: the Hungarian performance at the Brussels expo was supposed to improve the country's image abroad. ${ }^{48}$ Hungary's reputation was extremely negative at the time, two years after the suppressed revolution. The restored Communist regime of János Kádár, ${ }^{49}$ backed by the Soviet Union, had been carrying out a massive campaign of retaliation; thousands of people had been imprisoned for their participation in the Revolution of 1956, and prominent leaders of the revolution were executed even in 1958, two years after the uprising.

From about 1960, however, travel opportunities, including professional trips as well as holiday tourism abroad, were gradually becoming available again for Hungarians. Hungary's increased openness was in many ways related to the new policies which emerged in the Soviet Union under Nikita Khrushchev. As he broke with several key elements of Stalin's policies, Khrushchev also put an end to the strict and complete isolation of the Soviet Union from the Western world. Friendlier relations with Western powers meant, among other things, the Soviet Union's readiness to enter into peaceful competition with the West in the fields of science, technology and culture; Soviet artists, filmmakers and scholars of the Khrushchev era were allowed to participate in international symposiums, conferences, film festivals and other similar events. ${ }^{50}$ Albeit with limits and under state control, Soviet citizens could in general enjoy a greater freedom to travel than they had under Stalin, although the great majority of travel destinations remained within the Soviet sphere of influence. ${ }^{51}$

As a consequence of the new winds in the Soviet Union, most of the satellite countries - Hungary among them - began to liberalize their travel policy, and artists, intellectuals, scientists and professionals from Eastern Bloc countries began to appear at international events alongside their Soviet colleagues in greater and greater numbers. ${ }^{52}$

What was unique about Hungary in the 1960s (and even more so in the 1970s and 1980s) was the degree to which its political leadership permitted its citizens to visit foreign countries, including even individual forms of travel to non-Communist states. From about 1960, the expansion of travel opportunities became an integral

\footnotetext{
${ }^{48}$ T. Legát, 'Nagyot lőtt a gulyáságyú: magyarok az 1958-as brüsszeli expón', in Magyar Narancs online, 8 Dec. 2016, 8, http://magyarnarancs.hu/lokal/nagyot-lott-a-gulyasagyu-101840, last accessed 3 Aug. 2018.

${ }^{49}$ János Kádár (1912-89), head of the state party from 1957 to 1988. After the suppression of the 1956 revolution, the party was renamed MSZMP or Magyar Szocialista Munkáspárt (Hungarian Socialist Workers' Party). In certain periods, Kádár held other offices besides being the party's first secretary.

${ }^{50}$ Takács, 'Szovjet és magyar nyitás', 33-5.

${ }^{51}$ Ibid.

${ }^{52}$ Ibid., 32-3.
} 
element in the policies aimed at the consolidation of the Kádár regime, affecting every professional group and the Hungarian population as a whole. Besides other measures, such as satisfying consumer demands and the approval of a certain degree of cultural openness, the controlled but existing freedom of travel was supposed to ensure Hungarian citizens' loyalty to the regime.

Architects could again travel and attend conferences and symposiums, although at the beginning mainly in Eastern Bloc countries. Pál Granasztói, who had by that time developed a keen interest in historic towns and old districts - an inclination that he himself considered somewhat anachronistic at the time, in the most triumphant phase of high modernism - mentions a number of congresses he attended in East Germany and Czechoslovakia. The conference in Erfurt, East Germany, in 1956 was the first occasion on which he had a sense of reinforcement: the entire international conference was devoted to historic towns and their conservation. ${ }^{53}$

Other sources too mention conference trips to non-Communist countries in the post-1960 period. For example, architect Gábor Locsmándi (1942- ) whose name was later closely associated with urban revitalization in Hungary, made his first Western trip to Salzburg, Austria, in the late 1960s on the initiative of his department chair, Imre Perényi (1913-2002). Locsmándi, at that time a young assistant professor at the Urban Planning Department of the Budapest Technical University (Budapesti Múszaki Egyetem), participated in an international symposium where he clearly sensed the difference between the new currents in urban planning and the approaches he had studied during his earlier training ${ }^{54}$ (he had graduated from the Budapest Technical University in 1965).

Delegations sent to other countries to study good practices, in-progress or completed projects and new technologies were a common form of knowledge transfer between the mid-1950s and 1989 in all fields, architecture and urban planning included. The most common form of exchange involved mutual visits of experts from COMECON countries, but professional relations with non-Communist states were becoming increasingly common as well. Tamás Dragonits (1925- ), who was the leading architect on the project to reconstruct the Buda Castle's residential district (burghers' town) recently recalled his memories of co-operation between Swedish and Hungarian delegations on monument protection issues. Delegations played a crucial role in transfers of heritage protection, and mediated monument conservation principles and practices. ${ }^{55}$

\footnotetext{
${ }^{53}$ Granasztói, Itthon éltem, 709-12.

${ }^{54}$ G. Locsmándi, 21 Nov. 2020, interview by E. Szívós (digital audio recording), recording in the possession of E. Szívós.

${ }^{55}$ J. Jankó, 'Az itt lakók életében is van valami műemlék jellegü', 'Beszélgetés Dragonits Tamással, a Várnegyed egykori építészével’ (interview with Tamás Dragonits, former architect of the Castle District), MúzeumCafé, 10 (2016), http://muzeumcafe.hu/hu/romokbol-lett-kis-falu-varos-kozepen/, last accessed 31 Mar. 2020. On Dragonits' life, career and his connections to Sweden, see M. Palasik, A Müegyetemisták Odüsszeiája 1944-46 (Budapest, 2007); 'Fehér köpeny és rajzasztal': Mészáros Âbel beszélgetése Dragonits Tamással. Lechner Tudásközpont, 29 Nov. 2016, Életrajzi összefoglaló (Á. Mészáros' conversation with Tamás Dragonits. Written summary of T. Dragonits' life and career), https://epiteszforum.hu/feher-kopeny-es-rajzasztal-beszelgetes-dragonits-tamassal, last accessed 12 Feb. 2020 .
} 
Gábor Aczél, architect and urban planner, who participated in various urban planning projects from the late 1970s - including his prize-winning plan of 1983 for the complex renewal of the historic city centre in Györ, a city in Western Hungary - also mentioned instances of co-operation with Finnish, German, Romanian and Belarusian colleagues, involving trips of delegations, guest lectures and visits to project sites. ${ }^{56}$ Aczél mentioned cases when he and his colleagues, already renowned experts in historic inner cities' renewal, disseminated their knowledge in Eastern Bloc countries during the 1980s, giving presentations to employees of local planning companies in various Romanian, East German and Belarusian cities. In Grodno, for example, they delivered a lecture on the principles and practice of old city centres' revitalization, including traffic issues, and managed to convince local planners to create a car-free pedestrian zone in the city's historic core. ${ }^{57}$

Hungarian conservationists are well known to have been involved in broad international networks and co-operative projects in the 1970s and 1980s, ${ }^{58}$ which most probably contributed to the often-quoted high standards of Hungarian monument conservation during that period. ${ }^{59}$ Writing about the international relations of the profession, Melinda Harlov points out that András Román, who worked at the National Supervisory Bureau (Országos Műemléki Felügyelőség) as architect, conservation expert and urbanist, and later represented international organizations such as ICOMOS (International Council on Monuments and Sites) in Hungary, participated in innumerable professional visits and programmes in all parts of the world. ${ }^{60}$ Similarly she notes that Professor Walter Frodl, president of the (Austrian) Bundesdenkmalamt (Federal Office of Monuments) in Vienna, often visited Hungary bringing his students to the city of Sopron and other western Hungarian locations, in order to acquaint them with Hungarian monuments and their conservation. ${ }^{61}$

Planning in Budapest was also influenced by the international contacts of its leading experts and the activities of those experts abroad. The chief planners and research experts at BUVÁTI, the urban planning company of Budapest subordinated to the city council, went on regular business trips to Austria as well as other Western European countries. In some cases, they presented plans and concepts by members of their departments to professional audiences abroad, as did Gábor Preisich, formerly chief architect of Budapest (1953-55), then director of BUVÁTI's urban planning department (1956-70) and active urban planner until his retirement in $1975 .{ }^{62}$ The head of BUVÁTI's urban research department, Dr

\footnotetext{
${ }^{56}$ G. Aczél, 25 Feb. 2020, interview by E. Szívós (digital audio recording), recording in the possession of E. Szívós.

${ }^{57}$ Ibid.

${ }^{58}$ Harlov, 'Müemlékvédelem'.

${ }^{59}$ P. Lővei, 'Örökségvédelem versus műemlékvédelem: a nagy hal megeszi a kis halat', in E. Szívós and D. Veress (eds.), Örökség, történelem, társadalom (Budapest, 2020), 9.

${ }^{60}$ Harlov, 'Műemlékvédelem', 27. Based on the curriculum vitae of András Román on the website of ICOMOS Hungarian National Committee, http://icomos.hu/roman-andras/, last accessed 25 Sep. 2016, quoted in Harlov, 'Műemlékvédelem', 27 n. 38.

${ }^{61}$ Ibid. Based on D. Dercsényi, 'Walter Frodl 75 éves', Magyar Müemlékvédelem (1984), 463-5. Quoted in Harlov, 'Müemlékvédelem', 27 n. 39.

${ }^{62}$ Locsmándi, 21 Nov. 2020, interview.
} 
István Szücs, had regular teaching contracts abroad; he taught at the Graz University of Technology (Technische Universität Graz) in Austria on an annual basis during the late 1970s and early 1980s. ${ }^{63}$ Beginning in the mid-1970s, Szücs and his department were responsible for several urban sociology surveys carried out in the inner districts of Budapest. Using the methodology pioneered by Iván Szelényi (1938-), the BUVÁTI research team provided empirical data on the unfavourable demographic and sociological developments affecting the historic Inner City which prompted the emergence of urban renewal policies after 1975. ${ }^{64}$ Thus, Szücs's professional experiences in Austria can be directly related to his own activities and to the philosophy of urban revitalization taking root in the Hungarian capital.

Another former member of BUVÁTI's research department, mathematician and sociologist Iván Tosics (1952- ) benefited from professional contacts while working at his later company ÉGSZI (Institute for the Organization of Construction Economy - Építésgazdasági és Szervezési Intézet) from 1983. This company had close contacts with similar firms inside and outside the COMECON, which involved regular business trips in all directions. Returning the annual visits of Swedish delegations, the company sent members of his own crew to Sweden on an annual basis, where they were hosted by the National Swedish Institute for Building Research in the city of Gävle. ${ }^{65}$

This is how Iván Tosics met Bengt Turner, a Swedish researcher with whom he shared many common interests. Bengt Turner organized the first international conference on housing in 1986 and soon - in 1988 - founded the European Network of Housing Research. Tosics was invited by Turner to the 1986 conference in Sweden, and, albeit under the strict supervision of his company's management, his trip was finally approved; he presented a paper on the housing situation in late socialist Hungary. Even more importantly, Tosics became a founding member and permanent participant of the European Network of Housing Research (currently, he serves as the vice chairman of ENHR). Soon after Tosics's trip to Sweden, Bengt Turner was also invited to Budapest by the head of ÉGSZI's housing reform team, and exceptional as it was in late socialist Hungary - was able to spend a whole month in Budapest researching the documents of the Hungarian housing reform, at that time in the making. ${ }^{66}$ Tosics's work as a researcher has been closely associated with inner-city revitalization and housing issues since the mid-1970s, himself becoming a leading expert in the field by the 1990s. Thanks to his international embeddedness and expertise, models and ideas from Western and North-western Europe found their way into Hungarian urban housing policy, including the policies related to historic inner cities' renewal. Two years before the fall of the state socialist regime in Hungary, he and his colleagues organized a tour for facility management companies' employees; together, they visited Sweden, Holland and the

\footnotetext{
${ }^{63}$ I. Tosics, 22 Jan. 2021, interview by E. Szívós (digital audio recording), recording in the possession of E. Szívós.

${ }^{64}$ I. Szűcs and M. Balázsné Varga's urban sociological survey on Belső-Erzsébetváros (Inner Elizabethtown or the Inner VIIth District), referenced earlier in this article, was among the first such surveys carried out in Budapest.

${ }^{65}$ Tosics, 22 Jan. 2021, interview.

${ }^{66}$ Ibid.
} 
United Kingdom, meeting local experts and studying diverse models of the housing sector.

As demonstrated above, attending professional events in Western Europe, sometimes even in the United States, became a more and more plausible opportunity for Hungarians in the 1960s, 1970s and 1980s. During those decades of the Kádár regime, architects, civil engineers and urban planners again had the chance to work abroad, primarily in 'friendly' Communist countries or in countries of the developing world, but not exclusively. For example, architect Béla Borvendég (1931-2014), mentions a case when groups of young Hungarian architects, himself included, were officially permitted to travel to Great Britain between 1960 and 1962, and spend years as trainees at the London firm of Ernő Goldfinger (1902-87), an architect of Hungarian descent and of high international reputation; as an established architect in Britain, Goldfinger was well known in the 1960s and 1970s for his high-rise functionalist buildings. In his article written in 2002, Borvendég himself emphasized how unlikely that chance appeared to be in the early 1960s, and how much he learnt personally and professionally from his period in London. ${ }^{67}$

Besides conference participation and employment abroad, scholarships and research grants also helped some people to gain experiences in foreign countries. Research or other grants to Western Europe and the United States were extremely difficult for Hungarians to obtain, but not impossible; grants were sponsored, for example, by the UN or its organizations such as UNESCO or WHO. In certain cases, grantees worked as interns or were employed in other ways by Western European companies.

In other cases, Hungarian professionals were informed about open positions abroad through various channels and could simply apply. 'At that time [in 1974], the UIA [Union Internationale des Architectes] posted a job announcement at its Paris headquarters, for which they were specifically looking to hire a young person "from an Eastern country". I applied for the position, and I soon landed in Paris when negotiations began to turn serious', wrote Gábor Aczél in his memoirs. ${ }^{68}$ But finally the Hungarian authorities vetoed his plans, and Aczél was informed through the Alliance of Hungarian Architects (Magyar Építőmüvészek Szövetsége) that he would be denied the possibility to work in Paris 'due to some administrative or other problem'. As a form of compensation, he was offered a job in Algeria, and worked in Algiers from 1975 to 1977.

From the early 1970s, Hungarian architects and planners could participate in international architectural tenders and urban planning competitions, provided they learnt about the announcements and had the necessary amount of hard currency to get access to the detailed calls for the tenders in question. Aczél, for example, mentions an urban planning tender announced by the city of Florence, Italy, at which he and a Hungarian colleague, Ilona Zlamál, both participated. ${ }^{69}$ Another source, Dr Ferenc Callmeyer, architect and titular professor, mentions

\footnotetext{
${ }^{67}$ B. Borvendég, 'E, mint Goldfinger', epiteszforum.hu, 18 Sep. 2002, http://epiteszforum.hu/e-mintgoldfinger, last accessed 20 Feb. 2020.

${ }^{68}$ G. Aczél, Kalandozások Urbanisztikában (Budapest, 2009), 25. Quote translated by Erika Szívós.

${ }^{69}$ Ibid.
} 
an urban planning competition by the city of Bilbao at which he and another Hungarian architect, Tibor Tenke, competed against each other (and against the other applicants). ${ }^{70}$

Architects' and other technical experts' employment abroad was always controlled through a Hungarian state agency called TESCO Foreign Trading Company (TESCO Külkereskedelmi Vállalat), founded in 1962 in Hungary (and not to be confused with the Britain-based supermarket chain!). TESCO, whose name was an acronym for International Organization of Technical and Scientific Assistance, ${ }^{71}$ mediated professionals to foreign countries and supervised their work contracts. The TESCO Foreign Trading Company sometimes also lent money in hard currency to Hungarian architects so that they could participate in foreign tenders. ${ }^{72}$ In such situations, the applicants did not usually enter the tenders as private individuals but as representatives of their Hungarian planning companies. In other cases, TESCO recommended Hungarian companies as contractors to foreign partners. ${ }^{73}$ So TESCO, itself a state-owned corporation, clearly acted as an arbitrator of Hungarian knowledge export, and, through its activities, socialist Hungary's economy would benefit from its experts' employment abroad - often in the most direct financial sense. As one interviewee put it: 'We got paid through TESCO. But no one ever knew exactly how much TESCO skimmed off the top. ${ }^{, 74}$

These opportunities provided chances of mobility across the Iron Curtain and made it possible for Hungarian professionals to get acquainted with current trends and ideas in architecture and urban design. It is important to emphasize again the multidirectional possibilities for Hungarian - and, in general, Central and Eastern European - architects, planners and engineers: there was a steady demand for 'Second World' experts' knowledge in 'Third World' countries during the 1960s, 1970s and 1980s, so they could choose from a relative abundance of work assignments. Zoltán Ginelli has interpreted such connections in the post-colonial context, calling attention to the links between the semi-peripheral position of 'Second World' countries and the demands posed by new, emerging states after decolonization. ${ }^{75}$

Working in 'Third World' states did not only mean encounters with planners and local politicians of African, Middle Eastern, Middle Asian or Far Eastern countries; it also provided the opportunity to meet architects, civil engineers and other experts from the developed world. In the post-colonial period, it was obviously cheaper for developing countries to contract engineers, architects and planners from the 'Second World', but professionals from the former colonizing states such as France and Britain in some cases also accepted work assignments in the

\footnotetext{
${ }^{70}$ Speech by Ferenc Callmeyer at the inauguration of Tibor Tenke's memorial stone, in Negyven év II, www.bpxv.hu/hirek/negyven-ev-ii-kepes-beszamolo-a-cikk-vegen, last accessed 30 Mar. 2020.

${ }^{71}$ Z. Ginelli, 'Hungarian experts in Nkrumah's Ghana. Decolonization and semiperipheral postcoloniality in socialist Hungary', Mezosfera, 5 (2018), http://mezosfera.org/hungarian-experts-in-nkrumahs-ghana/, last accessed 2 Feb. 2021.

${ }^{72}$ Aczél, Kalandozások Urbanisztikában, 41. See also Aczél, 25 Feb. 2020, interview.

${ }^{73}$ Ibid.

${ }^{74}$ Ibid.

${ }^{75}$ Ginelli, 'Hungarian experts in Nkrumah's Ghana'; for architects from the entire region, see $€$. Stanek, 'Introduction: the "Second World's" architecture and planning in the "Third World", Journal of Architecture, 17 (2012), 299-307.
} 
former colonies; experts and companies of other developed countries such as the Federal Republic of Germany or the United States were also involved in certain projects. Project crews often consisted of workforces from the most diverse countries, Western and Eastern Bloc states alike. ${ }^{76}$ 'Third-World' project sites hence may have become places of East-West encounters.

Among the conditions of increasingly free private tourism and professional travel, some professionals seized the opportunity to escape and never returned to Hungary. The estimated number of those Hungarians who emigrated illegally between 1957 and 1990 roughly equalled the number of those who left permanently during the 1956 revolution, amounting to approximately $200,000 .{ }^{77}$ Many of the illegal emigrants who left Hungary in the 1960s, 1970s and 1980s were professionals, architects among them, who took advantage of their already existing work connections and networks abroad. 'Half of those people who worked abroad did not return [to Hungary]', Gábor Aczél reminisced in his recent interview. ${ }^{78}$ And even if that estimate may sound like an overstatement, it clearly shows the way proportions were perceived by members of the technical professions.

The increasing availability of professional journals and literature also contributed to knowledge transfers and international exchange. From the 1960s on, there was a definite improvement in that field in Hungary, thanks to the relatively liberal cultural policy of the post- 1960 period. $^{79}$ While before 1956 it was practically impossible to get access to international journals in Hungary, and the information barrier between East and West was almost complete, from the 1960s onwards major libraries - including the library of the Hungarian Academy of Sciences - began to subscribe to certain journals published in Western Europe or overseas in almost every scholarly field, including various fields of engineering, architecture and urban planning. It is even more important that specialized libraries of the architectural profession subscribed to several internationally leading journals too, as Edit Lantos has systematically revealed in her recent research. ${ }^{80}$

Dezső Ekler, architect and former member of BUVÁTI's research department between 1978 and 1985, specifically stressed the role of the National Technical Information Centre and Library (Országos Müszaki Információs Központ és Könyvtár) in Budapest, where the latest issues of the world's leading architectural periodicals were always available; that was where he himself first got acquainted with the works of major representatives of post-modernist architecture and became aware of heritage-sensitive schools and trends which ran counter to the core principles of modernist planning. ${ }^{81}$ Equipped with that knowledge, Ekler delivered

\footnotetext{
${ }^{76}$ Aczél, 25 Feb. 2020, interview; Ginelli, 'Hungarian experts in Nkrumah's Ghana'.

${ }^{77}$ A. Lénárt, 'Emigration from Hungary in 1956 and the emigrants as tourists to Hungary', Hungarian Historical Review, 1 (2012), 371-2. See also P.P. Tóth, 'A vándormozgalom szerepe a magyar népességfejlődésben', in idem (ed.), Bevándorlás Magyarországra (Budapest, 2006), 47-121.

${ }^{78}$ Aczél, 25 Feb. 2020, interview.

${ }^{79} \mathrm{~A}$ recent volume on the cultural politics of the Kádár era is C. Cuevas-Wolf and I. Poggi (eds.), Promote, Tolerate, Ban: Art and Culture in Cold-War Hungary (Los Angeles, 2018).

${ }^{80} \mathrm{E}$. Lantos, 'A magyar építészek tájékozódási horizontja 1957 és 1965 közt', in E. Lantos and G. Uhl (eds.), Postera crescam laude recens. Tanítványi tisztelgés Keserü Katalin születésnapjára (Budapest, 2006), 82-110.

${ }^{81}$ D. Ekler, 9 Nov. 2020, interview by E. Szívós. Notes in the possession of the author.
} 
several lectures in 1981-83 to large audiences at various professional forums, alerting the Hungarian architectural profession to the changing trends worldwide and reinforcing the rising consciousness of historic architectural values in Hungary. ${ }^{82}$

Moreover, Hungarian planning companies' own libraries could boast similar journal subscriptions, making the most up-to-date trends and plans available to architects and planners employed there. ${ }^{83}$ After the nationalization of private architectural studios, engineering firms and private planning businesses had been carried out in 1948-49, all architects, urban planners, civil engineers, structural engineers and technicians in state socialist Hungary were organized into large, state-owned planning companies (e.g. VÁTI, KÖZTI, IPARTERV, MÉLYÉPTERV, UVATERV), as well as planning companies subordinated to cities' and counties' administrations (such as FÖTI, later BUVÁTI, BORSODTERV or MISKOLCTERV). Each of those companies specialized in a certain field of planning, thus enjoying a monopolistic position; they could subscribe to international journals in their respective fields at affordable rates. Soviet literature and journals, as well as the output of other Eastern Bloc countries, was of course much more easily available throughout the entire state socialist period; until the early 1960s, Western influences sometimes reached Hungary via Soviet mediation. But beyond the late 1960s, members of the architectural and planning professions in Hungary were less and less focused on Soviet developments and oriented themselves clearly towards new trends in the Western world. ${ }^{84}$

Without exception, every interviewee quoted in this article, be they an architect, planner or urban sociologist, emphasized the crucial role of foreign journals in the transmission of novel ideas and their impact on the transformation of urban planning experts' way of thinking in Hungary. Architect Dezső Ekler and urban sociologist Iván Tosics both stated that foreign journals were absolutely central in terms of orienting members of professions involved in architecture and urban planning; in their opinion, journals in fact played a much more important role in most urban experts' self-education than study trips abroad, given the existing but relatively limited opportunities of professional travel in the state socialist period. ${ }^{85}$

\section{The dark underbelly of deceptive freedom: international mobility under the surveillance of state security}

It would be a mistake, however, to be deceived by the relative mobility of professionals and the relative ease of international travel in the 1960s and 1970s. The freedom of individuals was severely curtailed, and not only by the official and tangible

\footnotetext{
${ }^{82}$ Ibid.

${ }^{83}$ Aczél, 25 Feb. 2020, interview. Gábor Aczél was working at the planning company VÁTI (Várostervezési Tudományos Intézet), responsible primarily for the urban planning of Hungarian cities outside Budapest; in the library of VÁTI, he had access to several major international architectural and planning journals.

${ }^{84}$ 'We did not really care what was happening east of us. We only subscribed to Western journals, and we were excited by the most interesting things published in these Western journals', Locsmándi, 21 Nov. 2020, interview.

${ }^{85}$ Tosics, 22 Jan. 2021, interview; Ekler, 9 Nov. 2020, interview; Aczél, 25 Feb. 2020, interview; Locsmándi, 22 Nov. 2020, interview.
} 
limitations posed by the state socialist regime. Every kind of international movement, outbound as well as inbound, was closely controlled by the authorities, and often monitored by Hungarian state security. ${ }^{86}$

Architects' and other professional groups' professional life and international mobility were both affected by surveillance. To begin with, architects were reported on at their workplaces, predictably by some of their colleagues who were undercover agents and co-operated with the secret police. One would assume that architects and urban planners belonged to a professional group which was not as exposed and therefore was not as intensely spied on as writers, journalists or filmmakers. But, in the light of the sources, that assumption clearly appears to be unfounded. Every professional group was monitored by state security, and as my own research testifies - the architectural profession was no exception. ${ }^{87}$ Secret surveillance at work was made relatively easy and efficient by the already mentioned fact that architects and planners were all employed by a limited number of large, state-run companies, whose personnel was thus spatially and organizationally concentrated.

Understandably, when architects and other experts worked abroad or participated at international events, the likelihood of being monitored or reported on was even higher. If they were contracted for longer periods of work in foreign countries, their personal files were routinely checked by state security before they signed their contracts. ${ }^{88}$ If operative agents inside the candidate's company reported about the candidate's alleged intent to emigrate, i.e. not to return to Hungary from his or her employment abroad, state security officers proposed that the Ministry of Interior should withdraw - or not issue - the candidate's service passport. ${ }^{89}$ The minimum precaution was that the candidate, that is, the future grantee or employee who was about to work or study abroad, was summoned to the Hungarian Ministry of the Interior, where he or she was sufficiently 'prepared' for the potential dangers, namely that the foreign (intelligence) services of the target country would try to recruit him or her to work for them. An architect, employee of the planning company IPARTERV and mentioned by name in a security file, had gone through exactly that kind of procedure ${ }^{90}$ - and numerous other instances could be mentioned from the related archival files. Also, professionals

\footnotetext{
${ }^{86} \mathrm{~A}$ recent volume on the structure, activities and scope of post-Stalinist secret services in Hungary and elsewhere in Central Europe is Gy. Gyarmati and M. Palasik (eds.), Continuities - Discontinuities: Secret Services after Stalin's Death in Communist Central and Eastern Europe (Budapest and Pécs, 2017).

${ }^{87}$ Állambiztonsági Szolgálatok Történeti Levéltára (Historical Archives of State Security Services, henceforth ÁBTL) 3.1.2. M-23749/2 'Reményi Lajos'. The agent under this code name reported on several dozen architects within one of the state-owned planning companies. Another of his files, ÁBTL 3.1.2. M-13287/1, reveals his even more extensive activities related to several planning companies and to the membership of the Alliance of Hungarian Architects. Another agent in the same category was 'Szakértö' ('Expert'), who likewise operated inside the architectural and planning profession; see the file ÁBTL 3.1.2. M-16475.

${ }^{88}$ See the case of two architects, both employees of VÁTI, about to be contracted to work as UNO experts abroad. The state security officer in this document (1970) proposed reviewing the two professionals' personal dossiers on file at the TESCO Foreign Trading Company, ÁBTL 3.1.5. O-14242/4. 26. In another document, the officer stated that they had no objections to the two architects' employment abroad, ibid., 27.

${ }^{89}$ See e.g. ÁBTL 3.1.5. O-14242/4. 21. (1969).

${ }^{90}$ See e.g. the case of an architect employed at IPARTERV in the file of the agent under the code name 'Raduly Aladár', ÁBTL 3.2.4. K-2171 'Raduly Aladár'.
} 
who in the 1960s and 1970s worked abroad in Western, 'capitalist' countries and returned to Hungary afterwards were often monitored and reported on. ${ }^{91}$

But there could be a higher price to pay. Before commencing their promising, long-term work assignments abroad, the candidates were sometimes approached by the state security, and were practically blackmailed: if they wanted to get their permissions from the Hungarian authorities to work abroad or start their fellowship studies, they were expected to co-operate with the state security services and become their undercover agents. Given the high prestige of study or work opportunities in Western countries, some of the candidates were unable to say no in such situations.

For example, an architect and military engineer operated as a secret agent under the code name 'Edison'; he was recruited by Department III/1 of the Hungarian Ministry of Interior in 1962, when, after winning a grant, he was about to start working at the Department of Natural Sciences at UNESCO in Paris. He sent reports about Hungarian engineers and architects who had illegally emigrated to France earlier; moreover, he reported on his own fellow employees and about the activities within UNESCO. ${ }^{92}$ On closer inspection, however, the files of 'Edison' clearly reveal the history of a person who acted under pressure. Once in Paris, he formally fulfilled his task (i.e. wrote regular reports on persons in his office), but was clearly unable to deliver the kind of concise information on French academic institutions, research capacities and technologies which his ambitious superiors at the Hungarian Ministry of the Interior expected him to provide. ${ }^{93}$

International professional relations, including the contacts of Hungarian architects with their émigré Hungarian colleagues living abroad, were routinely burdened by state security surveillance. The émigré architects whose names one encounters in other architects' memoirs - or, for that matter, in professional journals of the Western world - appear in Hungarian state security files as well. These architects had left Hungary either as already experienced professionals before 1949, or in 1956, or as young men who were then trained as architects in their new homelands in Western Europe, North America or Israel (in some cases, in South America or Australia). Many of them became renowned members of the architectural profession in their new countries. Some early émigrés, who had left Hungary in the inter-war period, became well-known and well-integrated architects abroad, like Erno" Goldfinger (mentioned earlier in this article) who graduated from the École des Beaux-Arts in Paris in 1929, and later settled in Great Britain; ${ }^{94}$ or internationally famous figures like Marcel Breuer (1902-81), one of the members and well-known architect-designers of the Bauhaus School. As is apparent from Pál

\footnotetext{
${ }^{91}$ See the file 'Returnees from capitalist countries', ÁBTL 3.1.5. O-17160, containing cases from 1967 to 1978; the monitoring of returnees has been also mentioned by Gábor Aczél. See Aczél, 25 Feb. 2020, interview.

${ }^{92}$ ÁBTL 3.2.2. Mt-829/1 'Edison'.

${ }^{93}$ ÁBTL 3.2.1. Bt-1328 'Edison', 42-4, 45-7.

${ }^{94}$ Goldfinger, who commenced his studies in Paris in 1923, was obviously affected as a young man by the so-called numerus clausus law of 1920 (Act XXV of 1920), which set restrictive quotas for Jewish students in Hungary, and, by doing that, forced several young Hungarians of Jewish descent to attend universities abroad. Many of them pursued international careers and acquired world renown later as scientists, scholars, artists, architects or filmmakers.
} 
Granasztói's memoirs and Béla Borvendég's reminiscences quoted earlier, Goldfinger, despite the fact that he had departed from Hungary at a young age, maintained contacts with Hungarian architects all his life. As mentioned before, he hosted a series of young Hungarian architects as trainees in his London firm in the early 1960s. ${ }^{95} \mathrm{He}$ also visited Hungary on numerous occasions from the early 1960 s onwards.

There were instances of émigré architects having been approached by Hungarian foreign intelligence on their visits to Hungary (when such visits became possible again), or abroad; these organs tried to convince internationally well-connected architects, natives of Hungary, to co-operate with them. Among other cases, they tried to approach Ernő Goldfinger, who in 1960 visited his former homeland upon the invitation of the Hungarian Alliance of Architects. His file reveals the Hungarian intelligence service's (unsuccessful) efforts, involving also manoeuvres in London, regarding his recruitment. ${ }^{96}$ The Archives of the Hungarian State Security Services have preserved other similar cases as well. It must be added, however, and that slightly brightens the picture, that most of those attempts by the Hungarian foreign intelligence proved to be unsuccessful, as documented in the files themselves.

\section{Conclusions}

The question of how cities are shaped is one of the key concerns for urban history. Urban planning concepts and their adoption by municipal or national governments often stand in the focus of attention; investigating the ways planning ideals and practices shift from one paradigm to another is particularly central to our understanding of modern cities' evolution.

It is no less important to understand, however, who the arbiters of change are and in which ways those actors participate in knowledge transfers, facilitating the transmission of novel ideas across borders and disseminating new practices in their own regions.

One goal of this article was to identify a paradigm shift in an Eastern Bloc country, exploring the ways international trends were adopted and philosophies of 'mild' urban renewal gained ground in Hungary during the late twentieth century. Another main goal was to explore the role urbanists and architects played in that process; it was an explicit aim to understand their points of orientation and identify the patterns of their international experiences.

As written sources as well as urbanists' personal narratives suggest, the shift towards heritage-sensitive urban planning was gradual rather than abrupt in Hungary, and some of its aspects, such as the establishment of organized and institutionalized heritage protection, can be traced back to the early years of the Communist regime. This may be somewhat surprising as that era has been conventionally noted for its disrespect for the architecture of former, 'bourgeois' and 'feudal' epochs. As shown in this article, the Communist state in Hungary - influenced

\footnotetext{
${ }^{95}$ Borvendég, 'E, mint Goldfinger'.

${ }^{96}$ ÁBTL 3.2.4 K-1521. 'Szinész' ('Actor') was a coded name by which the target person of the operations, namely Goldfinger, was referred to in the documents.
} 
by similar developments in the Soviet Union - did find ways to identify with the built heritage of pre-1945 periods, albeit in a selective manner, and exploited that heritage in diverse ways: for example, as patrimony of the 'socialist' nation and also as a touristic asset. Therefore, monument conservation and the maintenance of prominent heritage sites always received state funding in Communist Hungary, even in periods when historic city centres' extensive renewal was not yet among the priorities of central planning. Simultaneously with the first, truly large-scale mass housing programmes, for example, the early 1960s witnessed the beginnings of such ambitious projects in Hungary as the reconstruction of the Buda Castle and its entire 'burghers' town'.

All that said, the (belated) triumph of modernism in East Central Europe strongly overshadowed historically minded, heritage-sensitive urban policies for at least two decades. The decline of Stalinist aesthetics after 1953 brought about the rehabilitation of modernist ideals in the Soviet Bloc; from the mid-1950s on, architects, planners and decision-makers again endorsed the principles of functionalism and technocratic planning which the architectural profession in the Eastern Bloc had been temporarily forced to abandon in 1948. The period between the mid-1950s and mid-1970s focused heavily on the construction of mass-produced new housing and new public buildings, and, in general, paid scant attention to historic towns and old city cores. This was not at all specific to Communist Central and Eastern Europe; inner-city areas were largely ignored on both sides of the Iron Curtain during those decades, and the demolition of old, low-standard urban areas as a precondition of successful urban reconstruction enjoyed nearcomplete consensus among urbanists Europe-wide.

Considering the conflicting policies outlined above, the Communist period in Hungary - and elsewhere in East Central Europe - should be understood as a Janus-faced epoch in which respect for the architectural heritage of past ages did exist, even in the realm of central policy-making, but it regularly clashed with the practical goals, technocratic spirit and functionalist ideals of architects and decision-makers - at least until the end of the 1970s.

Just as the triumphant phase of officially endorsed modernism coincided with a similar phase in Western Europe, critical attitudes towards that paradigm emerged in East Central Europe roughly at the same time as in other regions of the continent. Ideas of urban renewal were gradually adopted in Hungary too from the mid-1970s, and by the end of that decade large-scale inner-city renewal programmes began to receive clear political support. And while in earlier decades the socialist practice of urban planning only held monuments - or built areas regarded specifically as heritage sites - worthy of protection, the late 1970s witnessed the emergence of heritage-sensitive approaches which recognized the values of historic architecture and rediscovered the attractive sides of old inner-city areas.

Hungarian architects, urban planners and other experts played a crucial role in the turning of the tide and were active agents of knowledge transfers between 1956 and 1990. They were exposed to pathbreaking ideas and practices through the international journals which they had access to in specialized libraries, through the study and work opportunities which gradually opened for them after 1960, and through the transnational networks in which they participated. Architects' and urban experts' mobility did not only bridge the East-West divide but was also 
multidirectional: besides travel within the Eastern Bloc and professional trips to the Western world, work contracts and assignments also took Hungarian experts to developing countries all around the globe. Between 1960 and 1990, it was a formative experience of whole generations of architects, planners and other urban experts to gather experiences abroad and mediate new knowledge to Hungary.

However, the relative freedom of private and professional travel, a distinctive characteristic of Communist Hungary between the early 1960s and 1990, needs to be assessed critically in retrospect. On the surface, Hungary invested enormous efforts into creating a favourable image of itself abroad after 1956, and, until the collapse of the Communist regime in 1990, hosted international tourists and business visitors with a level of hospitality that was unparalleled in other Eastern Bloc countries and was highly appreciated by guests from the Western world. It also granted its own citizens a relatively broad freedom to travel and work abroad. After 1960, Kádár's governments pursued policies of relative openness in several fields, making it possible for the current trends - including the ones in architecture, design and urban planning - to take root in Hungary. Several professionals, scholars and artists - including members of the architectural profession - had the opportunity to gain experiences abroad, and a whole range of fields and professions benefited from the new currents which their representatives mediated to Hungary. As this article has showed, however, those freedoms were always deceptive: control and surveillance belonged to the essence of the system and were constantly exercised, even when the regime went to great lengths to reward its citizens with the sense of extensive mobility.

Cite this article: Szívós E (2022). The historic city and the East-West exchange: architecture, urban renewal and international knowledge transfers under state socialism in Hungary. Urban History 49, 523-548. https://doi.org/10.1017/S0963926821000468 